\title{
Validation of the Turkish version Power of the Food Scale (PFS) for determining hedonic hunger status and correlate between PFS and body mass index
}

\author{
Akçil Ok Mehtap ${ }^{1 *}$ \& Hayzaran Melisa ${ }^{2}$ \\ ${ }^{1}$ Department of Nutrition and Dietetics, Faculty of Health Sciences, Başkent \\ University, Ankara, Turkey; ${ }^{2}$ Department of Nutrition and Dietetics, Faculty of Health \\ Sciences, Basskent University University, Ankara, Turkey
}

\begin{abstract}
Introduction: This study was carried out to determine the validity and reliability of the Turkish culture-adapted version of "Power of the Food Scale" (PFS), which was originally developed by Lowe et al. (2009). In addition, associations between body mass index (BMI) and PFS scores were assessed. Methods: The study sample consisted of a total of 363 volunteering students aged $>18$ years, who were studying at the Basskent University in Turkey. Validity and reliability analyses were conducted for the Turkish version of the PFS. Results: The correlations of each item in the PFS with the total score were found to be positive and $>0.30$. The Cronbach's alpha value was determined as 0.85 . The construct validity of the scale was analysed with confirmatory factor analysis. The Adjusted Goodness of Fit Index was 0.97 and the Root Mean Square Error of Approximation was 0.07. These fit indices of the model confirmed the construct validity of the PFS. A positive and statistically significant correlation was found between BMI values of the students and the total score of the scale $(r=0.157 ; p=0.003)$. Conclusion: The findings obtained in this study have laid out that the Turkish Power of Food Scale (T-PFS), which was adapted to Turkish culture from PFS, is a valid and reliable measurement tool that can be applied in Turkey. Thus, T-PFS is thought to be likely to contribute to studies aiming to determine the status of hedonic hunger.
\end{abstract}

Keywords: Hedonic hunger, power of food scale, Turkey university students

\section{INTRODUCTION}

Obesity is a global health problem that directly impacts $20 \%$ of the world's population. It is also a leading risk factor for mortality among non-communicable diseases such as metabolic syndrome, cancer and cardiovascular disease (WHO, 2017). Early adulthood represents a critical period in the development of obesity. Recent cross-sectional data have shown that the prevalence of overweight and obesity in adults aged between 20 and 39 years is almost twice that of adolescents aged between 12 and 19 years (Ogden et al., 2014). The prevalence of overweight and obesity in Turkey has increased considerably in adult males and females in the last 20 years. The results obtained from different periods showed that obesity is a significant and serious public health problem in Turkey (Erem, 2015).

Today, eating behaviour in humans is known to be mostly driven by the response to environmental triggers regarding foods, regardless of physiological needs

\footnotetext{
*Corresponding author: Prof. Dr. Akçil Ok Mehtap Department of Nutrition and Dietetics, Faculty of Health Sciences, Baskent University, Ankara, Turkey Tel: (+90) 0312 2466671; Fax: (+90) 0312 2466672; E-mail: makcil@baskent.edu.tr doi: https://doi.org/10.31246/mjn-2019-0129
} 
(Cleobury \& Tappert, 2014; Schüz, Schüz \& Ferguson, 2015). People eat not only when they feel hungry but also for pleasure due to the high availability of and easy access to food (Berthoud, 2011; Monteleone, Scognamiglio \& Monteleone, 2013). This is manifested in many phrases in the scientific literature, such as "hedonic eating", "emotional eating", "stress-induced eating", "food addiction", "eating to feel good", and "eating as a treatment". "Hedonic eating" is defined as a desire to consume food for motivation regardless of energy content (Lowe \& Butryn, 2007; Boggiano et al., 2015; Cappelleri et al., 2009; Berthoud, 2011). Hedonic eating motives individuals to consume even though the body does not need food. The types of foods generally consumed under these conditions are high energy products, which are processed and flavoured with a high content of fat, sugar, or salt (Boggiano et al., 2015; Burgess et al., 2014). A person's consumption of his/her favourite dessert despite being full after dinner is an example of this situation. With the consumption of food that gives pleasure, hedonic mechanisms increase food consumption by heading off our homeostatic mechanisms. Therefore, it is important to establish a balanced relationship between modern obesogenic lifestyle and food consumption (Lowe \& Levine, 2005; Dalton \& Finlayson, 2013).

This study aimed to carry out a validity and reliability assessment on the Turkish culture adapted PFS, which was originally developed by Lowe et al. (2009), to evaluate the feelings and thoughts of individuals about the consumption of food and nutrition without a metabolic necessity in the environments where delicious foods are widely available.

\section{MATERIAL AND METHODS}

\section{Ethics}

For the study, 'Research Board Approval' was obtained from the Basskent University Medical and Health Sciences
Research Board with the decision number 94603339-604.01.02 / 12617 and dated 04.04.2017.

\section{Permission}

Permission to use and translate the scale was obtained from the creator of the scale Lowe MR et al. via email. At the same time, a mutual agreement was signed. The Turkish version of the scale was also shared with the authors.

\section{Participants}

The sample of this study consisted of a total of 363 volunteering students aged over 18 years, including 293 females and 70 males, who were studying at the Basskent University in Turkey. There are a total of 11 faculties at the Basskent University and a total of 41 departments under these faculties. The sample of the study included classes and departments from these faculties to ensure that each faculty was represented in the sample. In adapting a scale to a different language and culture, the recommended sample size to determine its validity and reliability should be at least 5-10 times the number of the items in the scale (Osborne \& Costello, 2004). Sample selection was conducted according to the Simple Random Sampling technique by assigning numbers to faculties and departments and generating random numbers in the Excel computer software. Permissions were obtained from the faculties and departments, which were selected in the sampling procedure, and then the questionnaire was administered to the students in their classrooms.

\section{Questionnaire form}

The first section of the questionnaire collected information about the demographic characteristics of the students such as age, gender, and body mass index (BMI). The rest of the questionnaire was the 21-item Turkish adapted version of PFS, which composed of three factors (food availability, food 
presence and food taste, respectively). The questionnaire was self-administered by the students in their classes under the supervision of the researchers.

\section{BMI measure}

Height $(\mathrm{cm})$ and body weight $(\mathrm{kg})$ values of the students were taken. BMI was calculated by dividing weight $(\mathrm{kg})$ by the square of height (m).

\section{Translation of the original form of the PFS into Turkish}

To adapt the PFS into Turkish, first of all, the original form of this 21-item scale was translated into Turkish. The standard translation-back-translation method was used in the translation process of this questionnaire (Beaton et al., 2000). For this purpose, a total of three experts, including two experts who had a good command of English in the field of nutrition and a faculty member with an advanced level of English from the Basskent University Faculty of Health Sciences first translated the scale into Turkish. Then the translated form was translated back into English from Turkish. The Turkish adaptation process of the scale was finalised after the most recent translated forms had been evaluated in terms of consistency and semantic integrity, and that necessary amendments had been made.

To determine the intelligibility of the scale in terms of language and meaning, it was submitted to the instructors from the Department of Nutrition and Dietetics for review and evaluation. Besides, the scale was piloted to approximately 20 students from different departments to determine the intelligibility of the items, the appropriateness of item sequencing, and the time needed for completing the scale. Accordingly, the opinions and suggestions of the students were collected. After making necessary amendments in the scale based on the feedbacks, it was then finalized and administered to the target sample group.
No problem was encountered during this stage.

\section{Statistical analysis}

After the adaptation of the scale into the Turkish language, for the Explanatory Factor Analysis, the Principal Component Factor Analysis was employed to determine the number of underlying factors (items) in the PFS. The fit between the Turkish version of the scale with the original form was analysed using Confirmatory Factor Analysis (CFA). Fit indicators such as Chi-square $\left(\chi^{2}\right)$ Goodness of Fit Index, Adjusted Goodness of Fit Index, Root Mean Square Residual, and Root Mean Square Error of Approximation indices were calculated. To determine the reliability between the items of the scale (internal consistency), item analysis and Cronbach's alpha coefficient were calculated. Correlations between the total score of the PFS scale and BMI values were analysed with Pearson's correlation analysis.

\section{RESULTS}

According to the findings, $80.7 \%$ of the students were females. The mean age of the students was $21.3 \pm 1.8$ years, and the average BMI was $21.80 \pm 4.07 \mathrm{~kg} /$ $\mathrm{m}^{2}$. While $70.6 \%$ of the students were under normal BMI classification (18.50$\left.24.99 \mathrm{~kg} / \mathrm{m}^{2}\right), \quad 12.5 \%$ and $3.0 \%$ were classified as slightly obese (25.00$\left.29.99 \mathrm{~kg} / \mathrm{m}^{2}\right)$ and obese $\left(>30.00 \mathrm{~kg} / \mathrm{m}^{2}\right)$, respectively. A positive and statistically significant correlation was found between the BMI values of the students and their PFS scale scores $(r=0.157 ; p=$ 0.003).

\section{Explanatory factor analysis of the PFS} In the study, Kaiser-Meier-Olkin (KMO) test was employed to test whether the sample size was adequate, and Bartlett's Sphericity Test was used to determine whether there was a correlation between the items, which is a prerequisite for 
factor analysis. Accordingly, the results of the KMO test statistics showed that the sample size was adequate $(\mathrm{KMO}=$ 0.87 ). A KMO value of $>0.50$ indicates that the sample size of the related scale data is sufficient. According to the Bartlett Sphericity Test result, the level of correlation between the items was found to be sufficient to do a factor analysis $\left(\chi^{2}=1493 ; p<0.0001\right)$.

As a result of the Explanatory Factor Analysis (EFA), 6 out of the 21 items were excluded from the scale as their factor loadings were $<0.30$ and they impaired construct validity. The same items had also been omitted from the original scale. The scale was then divided into 3 factors under the constraint of an eigenvalue $>1$. The factor loading for the items in each factor was $>0.30$, and the scale was found to explain $33.08 \%$ of the total variance. As shown in Table 1 , the items grouped under factor 1 were items $1,2,5,10,11$ and 13; those under factor 2 were items 3, 4, 6 and 7; and those gathered under factor 3 were items 8,9 , 12,14 and 15.

\section{Confirmatory factor analysis of the PFS}

In this study, the three-factor structure was tested based on the original form to determine the confirmatory factor validity of PFS. IBM SPSS AMOS 21.0 version (2012)'s Structural Equation Modelling was employed to analyse whether the collected data were appropriate for the model. The fit statistics of the model are shown in Table 2, and the fit scheme is presented in Figure 1.

Table 1. Items, factor loadings, eigenvalues, and variance explanation for the Turkish Power of Food Scale (T-PFS)

\begin{tabular}{lccc}
\hline Items & $\begin{array}{c}\text { Factor 1 } \\
\text { (Food Available) }\end{array}$ & $\begin{array}{c}\text { Factor 2 } \\
\text { (Food Present) }\end{array}$ & $\begin{array}{c}\text { Factor 3 } \\
\text { (Food Tasted) }\end{array}$ \\
\hline PFS 1 & 0.68 & & \\
PFS 2 & 0.70 & & \\
PFS 5 & 0.69 & & \\
PFS 10 & 0.64 & & \\
PFS 11 & 0.66 & & \\
PFS 13 & 0.65 & 0.68 & \\
PFS 3 & & 0.64 & \\
PFS 4 & & 0.61 & 0.48 \\
PFS 6 & & 0.64 & 0.73 \\
PFS 7 & & & 0.38 \\
PFS 8 & & & 0.66 \\
PFS 9 & & & 0.63 \\
PFS 12 & & & 1.09 \\
PFS 14 & & & 7.26 \\
PFS 15 & & & \\
Eigenvalue & & & \\
Variance & & & \\
explanation & & & \\
percentage & 3.96 & & \\
\hline
\end{tabular}




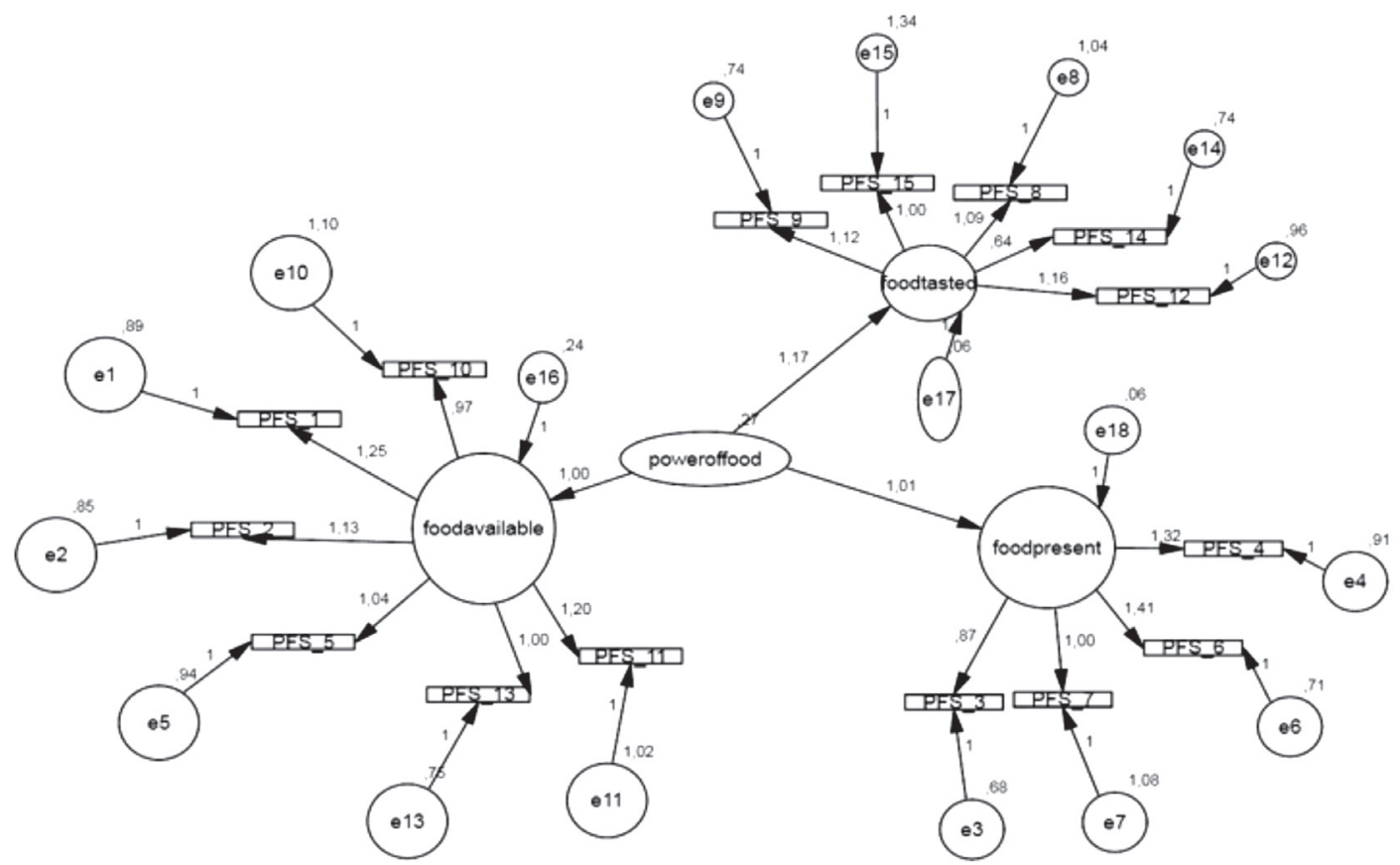

Figure 1. The fit scheme of PFS scale with confirmatory factor analysis and the three-factor model

Different indices can be used to evaluate the fit of a model. According to the Chi-square $\left(\chi^{2}\right)$ Goodness of Fit Index used in this study, the scale was observed to have a perfect fit. Besides, the Adjusted Goodness of Fit Index (AGFI) was found as 0.97. An AGFI value that is $>0.90$ shows that the model has goodness of fit. Similarly, a Root Mean Square Residual (RMR) value that is $<0.05$ and a value of Root Mean Square Error of Approximation (RMSEA) that is $<0.08$ too show the model has goodness of fit. In this study, the RMR was 0.048, and the RMSEA was 0.07. With that, the values obtained from this scale indicated the acceptability and applicability of the Turkish version of the PFS (Table 2).

As shown in Figure 1, the results of the "two-level confirmatory factor analysis" were obtained by adding 'power of food', which is an upper-level factor (latent variable), explained by three factors (latent variables) in the model. The items linked to each factor, the number of errors, and the regression coefficients explaining them are given in Figure 1. The Turkish version of the PFS was confirmed by obtaining the same results as the original scale.

Table 2. The fit statistics of the PFS scale according to confirmatory factor analysis

\begin{tabular}{lll}
\hline Fit indexes & Cutoff Criteria in the Literature & Turkish PFS scale results \\
\hline$\chi^{2} / \mathrm{df}$ & $3-5$ & 4.80 \\
AGFI & $\geq 0.90$ & 0.97 \\
RMR & $\leq 0.05$ & 0.048 \\
RMSEA & $0.06-0.08$ & 0.07 \\
\hline
\end{tabular}




\section{Reliability analysis for internal consistency}

The level of internal consistency (reliability) between the items in the PFS was calculated by item-total correlations and Cronbach's alpha internal consistency coefficients. Cronbach's alpha internal consistency coefficient was found to be 0.85 for the PFS. Cronbach's alpha internal consistency coefficient yields a value of between 0 and 1 . The closer this coefficient is to 1 , the more reliable the tool is.

As is seen in Table 3, the correlations of all items with the total score were positive and $>0.30$. This indicated that the scale as a whole could measure the power of food on individuals. Besides, the reliability coefficients (Cronbach's alpha) for the three subscales of PFS approved by CFA were 0.80 for factor 1 (food availability), 0.67 for factor 2 (food presence), and 0.69 for factor 3 (food taste). These results showed that each factor had adequate reliability. Two-month test- retest reliability in the Başkent University sample $(n=90)$ was found to be adequate $(r=0.82 ; p<0.001)$.

\section{Score based evaluation of the PFS}

As stated by Lowe et al. (2009), the PFS consisting of three factors and 15 items is evaluated over a five-point Likert type scale. Each item is responded with one of the "strongly agree", "agree", "no idea", "disagree", and "strongly disagree" options. The scores of the options are 5, 4, 3, 2 and 1, respectively. An increased scale score of an individual meant an increase in the impact of power of food on the individual (hedonic hunger). The total score was divided by the number of items, and then the resulting mean score was interpreted. If the mean score was over 2.50 , it indicated the presence of hedonic hunger and showed that the individual is affected by food.

The students who participated in this study scored a minimum of 1.33 points, a maximum of 5 points, and an average of $3.18 \pm 0.68$ points from

Table 3. Reliability analysis results for the items of PFS

\begin{tabular}{ccc}
\hline Item & $\begin{array}{c}\text { Item-total scale } \\
\text { correlation }\end{array}$ & $\begin{array}{c}\text { Cronbach's alpha coefficient } \\
\text { if item deleted }\end{array}$ \\
\hline PFS 1 & 0.549 & 0.840 \\
PFS 2 & 0.498 & 0.843 \\
PFS 3 & 0.385 & 0.849 \\
PFS 4 & 0.542 & 0.841 \\
PFS 5 & 0.506 & 0.843 \\
PFS 6 & 0.562 & 0.840 \\
PFS 7 & 0.387 & 0.849 \\
PFS 8 & 0.501 & 0.843 \\
PFS 9 & 0.532 & 0.842 \\
PFS 10 & 0.442 & 0.846 \\
PFS 11 & 0.561 & 0.840 \\
PFS 12 & 0.527 & 0.842 \\
PFS 13 & 0.555 & 0.840 \\
PFS 14 & 0.333 & 0.851 \\
PFS 15 & 0.397 & 0.849 \\
\hline
\end{tabular}


the scale. Besides, the students were found to have an average of $2.78 \pm 0.88$ points from the first subscale "food availability", $3.43 \pm 0.81$ points from the second subscale "food presence", and $3.33 \pm 0.79$ points from the third subscale "food taste".

\section{DISCUSSION}

This study aimed to adapt the threesubscale, 15-item PFS, which was developed by Lowe et al. (2009), to the Turkish culture. The adaptation process started with the translation of the scale from the source language to the target language and went on with the determination of linguistic and idiomatic equivalences, and then pilot administration. Finally, the Turkish version of the PFS was administered to 363 university students, and the data obtained were analysed.

The results found in this study were similar to the results of the PFS developed by Lowe et al. (2009). Cappelleri et al. (2009) examined the validity and reliability of the PFS in two separate sample groups - one including obese individuals and the other on a sample of the general population. They concluded that the PFS, which consisted of 15 items and three factors had a reliability coefficient that ranged between 0.81 and 0.91. Mitchell et al. (2016) studied the psychometric properties of PFS in a sample of preadolescents and adolescents $(n=148)$. The result of CFA in their study also indicated that the items in the scale were loaded under three factors as in the original. They found that Cronbach's alpha coefficient for the total score and the three factors ranged from 0.86 to 0.95 . The results obtained using a sampling of pre-adolescents and adolescents were similar to the results of our study conducted on university students.

In our study, positive and statistically significant correlations were found between the BMI of the students and their PFS scale scores $(r=0.157$; $p=0.003)$. All three sub-factors were also found to be positively correlated with BMI, although statistical significance was only determined in the food availability subscale $(r=0.251 ; p<0.001)$. In their narrative review on hedonic hunger measured by PFS, Espel Huynh et al. (2018) found a positive correlation between BMI and PFS in 8 out of 10 studies. These results also supported the finding that increased PFS score clearly showed hedonic hunger. Determination of individuals' hedonic hunger levels will provide important information about their tendency to become obese. Thus, clinicians/dietitians and similar healthcare professionals may evaluate their patients using PFS to determine their hedonic hunger level, and perhaps recommend a treatment/diet programme accordingly.

The first limitation of this study was the inclusion of students from a single university in the sample. Perhaps it would be more appropriate to work with a larger sample group covering the whole country. The second limitation of the study was the absence of another scale in the study that measures eating behavior. Compensation for these constraints in future studies and comparison with our results will further increase the scientific value of the PFS.

\section{CONCLUSION}

PFS is a scale used to determine the status of hedonic hunger. The findings obtained indicated that the Turkish version of the PFS, which was adapted from the original PFS, is a valid and reliable instrument that can be applied in Turkey. It is thought that PFS will contribute to studies aiming to determine the status of hedonic hunger.

\section{Acknowledgement}

The authors are grateful to the Basskent University Administration and the students who participated in the research. 


\section{Authors' contributions}

AOM, principal investigator, conceptualised and designed the study, analysed and interpreted the data, prepared the draft of the manuscript and reviewed the manuscript; HM, led the data collection and design of the research, conducted the study and wrote the manuscript.

\section{Conflict of interest}

Authors declare no conflict of interest.

\section{References}

Aliasghari F, Jafarabadi MA, Yaghin NL \& Mahdavi R (2018). Psychometric properties of Power of Food Scale in Iranian adult population: genderrelated differences in hedonic hunger. Eating and Weight Disorders-Studies on Anorexia, Bulimia and Obesity. https://doi.org/10.1007/ s40519-018-0549-3

Beaton DE, Bombardier C, Guillemin F \& Ferraz MB (2000). Guidelines for the Process of CrossCultural Adaptation of Self-Report Measures. SPINE 25(24):3186-3191.

Berthoud HR (2011). Metabolic and hedonic drives in the neural control of appetite: who is the boss? Curr Opin Neurobiol 21:888-896.

Boggiano MM, Wenger LE, Turan B Tatum MM, Sylvester MD, Morgan PR, Morse KE \& Burgess EE (2015). Real-time sampling of reasons for hedonic food consumption: further validation of the palatable eating motives scale. Front Psychol 6:744.

Burgess EE, Turan B, Lokken KL, Morse A \& Boggiano MM (2014). Profiling motives behind hedonic eating. Preliminary validation of the palatable eating motives scale. Appetite 72:6672.

Cappelleri JC, Bushmakin AG, Gerber RA, Leidy NK, Sexton CC, Karlsson J \& Lowe MR (2009). Evaluating the power of food scale in obese subjects and a general sample of individuals: development and measurement properties. IJO 33:913-922.

Cleobury L \& Tappert K (2014). Reasons for eating 'unhealthy' snacks in overweight and obese males and females. J Hum Nutr Diet 27:333341.

Dalton M \& Finlayson G (2013). Hedonics, satiation and satiety. University of Leeds, UK. doi: 10.1533/9780857098719.4.221.
Erem C (2015). Prevalence of overweight and obesity in Turkey. IJC Metab Endocr 8:38-41.

Espel-Huynh HM, Muratore AF \& Lowe MR (2018). A narrative review of the construct of hedonic hunger and its measurement by the Power of Food Scale. Obes Sci Pract 161:238-249.

IBM SPSS AMOS 21.0 version (2012). Amos Development Corporation. Meadville, PA 16335 USA.

Lowe MR \& Butryn ML (2007). Hedonic hunger: A new dimension of appetite? Physiol Behav 91:432-439.

Lowe MR, Butryn ML, Didie ER Annunziato RA, Thomas JG, Crerand CE, Ochner CN, Coletta MC, Bellace D, Wallaert M \& Halford J (2009). The power of food scale. a new measure of the psychological influence of the food environment. Appetite 53:114-118.

Lowe MR \& Levine AS (2005). Eating motives and the contoversy over dieting: eating less than needed versus less than wanted. Obes Res 13:797-805.

Mitchell TB, Cushing CC \& Amaro CM (2016). Psychometric properties of the power of food scale in a community sample of preadolescents and adolescents. $J$ Child Fam Stud 25:27332739.

Monteleone P, Scognamiglio P, Monteleone AM Perillo D, Canestrelli B \& Maj M (2013). Gastroenteric hormone responses to hedonic eating in healthy humans. Psychoneuroendocrinology 38:1435-1441.

Ogden CL, Caroll MD, Kit BK \& Flegal KM (2014). Prevalence of childhood and adult obesity in the United States, 2011-2012. JAMA 311(8):806814.

Osborne JW \& Costello AB (2004). Sample size and subject to item ratio in principal components analysis. Pract Assess Res \& Eval 9:1-9.

Schüz B, Schüz N \& Ferguson SG (2015). It's the power of food: individual differences in food cue responsiveness and snacking in everyday life. Int J Behav Nutr Phy 12:149.

WHO (2015). World Heath Statistics. World Health Organization. From http://www.who.int/gho/ publications/world_health_statistics / 2015/ en/ [Retrieved November 20 2017]. 
Appendix 1. Original and Turkish language items for the Power of Food Scale (PFS)

\begin{tabular}{|c|c|c|}
\hline $\begin{array}{c}\text { Item } \\
\text { numbers }\end{array}$ & Original English language items & Turkish language items \\
\hline PFS 1 & $\begin{array}{l}\text { I find myself thinking about food even } \\
\text { when I am not physically hungry. }\end{array}$ & $\begin{array}{l}\text { Fiziksel olarak aç olmadiğım zamanlarda } \\
\text { bile kendimi yiyecek düşünürken } \\
\text { buluyorum. }\end{array}$ \\
\hline PFS 2 & $\begin{array}{l}\text { I get more pleasure from eating than I do } \\
\text { from almost anything else. }\end{array}$ & $\begin{array}{l}\text { Yemek yemek, başka bir şey yapmaktan } \\
\text { daha çok zevk veriyor. }\end{array}$ \\
\hline PFS 3 & $\begin{array}{l}\text { If I see or smell a food I like, I get a } \\
\text { powerful urge to have some. }\end{array}$ & $\begin{array}{l}\text { Sevdiğim bir yemeği gördüğüm ya da } \\
\text { kokusunu aldığim zaman, biraz yemek için } \\
\text { güçlü bir dürtü hissederim. }\end{array}$ \\
\hline PFS 4 & $\begin{array}{l}\text { When I'm around fattening food I love, it's } \\
\text { hard to stop myself from at least tasting it. }\end{array}$ & $\begin{array}{l}\text { Bulunduğum ortamda sevdiğim yağll/ } \\
\text { şişmanlatıcı yiyecekler varsa, kendimi } \\
\text { tadlarına bakmak için durdurmakta } \\
\text { zorlanıyorum. }\end{array}$ \\
\hline PFS 5 & $\begin{array}{l}\text { It's scary to think of the power that food } \\
\text { has over me. }\end{array}$ & $\begin{array}{l}\text { Besinlerin üzerimdeki gücünü düşünmek } \\
\text { oldukça korkutucu }\end{array}$ \\
\hline PFS 6 & $\begin{array}{l}\text { When I know a delicious food is available, } \\
\text { I can't help myself from thinking about } \\
\text { having some. }\end{array}$ & $\begin{array}{l}\text { Lezzetli bir yemeğin hazırda var olduğunu } \\
\text { bildiğimde, onu yeme konusunda kendime } \\
\text { engel olamıyorum. }\end{array}$ \\
\hline PFS 7 & $\begin{array}{l}\text { I love the taste of certain foods so much } \\
\text { that I can't avoid eating them even if } \\
\text { they're bad for me. }\end{array}$ & $\begin{array}{l}\text { Bazı besinlerin tadını o kadar çok seviyorum } \\
\text { ki, benim için zararlı olduklarını bilsem bile } \\
\text { onları yemeyi bırakamıyorum }\end{array}$ \\
\hline PFS 8 & $\begin{array}{l}\text { Just before I taste a favorite food, I feel } \\
\text { intense anticipation. }\end{array}$ & $\begin{array}{l}\text { Çok sevdiğim bir besini tatmadan önce, o } \\
\text { besinle ilgili yoğun bir beklenti içerisine } \\
\text { giriyorum }\end{array}$ \\
\hline PFS 9 & $\begin{array}{l}\text { When I eat delicious food I focus a lot on } \\
\text { how good it tastes. }\end{array}$ & $\begin{array}{l}\text { Lezzetli bir yemek yediğimde, tadının ne } \\
\text { kadar iyi olduğuna çok odaklanıyorum }\end{array}$ \\
\hline PFS 10 & $\begin{array}{l}\text { Sometimes, when I'm doing everyday } \\
\text { activities, I get an urge to eat 'out of the } \\
\text { blue' (for no apparent reason). }\end{array}$ & $\begin{array}{l}\text { Bazı zamanlarda, günlük aktiviteler } \\
\text { yaparken, 'aniden' yemek yeme isteği } \\
\text { duyuyorum (belirgin bir sebep yok iken). }\end{array}$ \\
\hline PFS 11 & $\begin{array}{l}\text { I think I enjoy eating, a lot more than most } \\
\text { other people. }\end{array}$ & $\begin{array}{l}\text { Diğer insanlara göre yemek yemekten daha } \\
\text { fazla zevk aldığımı düşünüyorum }\end{array}$ \\
\hline PFS 12 & $\begin{array}{l}\text { Hearing someone describe a great meal } \\
\text { makes me really want to have something } \\
\text { to eat. }\end{array}$ & $\begin{array}{l}\text { Biri bana çok güzel bir yemeği tarif } \\
\text { ettiginde, bir şeyler yeme istegi duyuyorum. }\end{array}$ \\
\hline PFS 13 & It seems like I have food on my mind a lot. & $\begin{array}{l}\text { Aklımin sürekli yemekle meşgul olduğunu } \\
\text { düşünüyorum. }\end{array}$ \\
\hline PFS 14 & $\begin{array}{l}\text { It's very important to me that the foods I } \\
\text { eat are as delicious as possible. }\end{array}$ & $\begin{array}{l}\text { Yediğim besinlerin mümkün olduğunca } \\
\text { lezzetli olması benim için çok önemlidir. }\end{array}$ \\
\hline PFS 15 & $\begin{array}{l}\text { Before I eat a favorite food my mouth tends } \\
\text { to flood with saliva. }\end{array}$ & $\begin{array}{l}\text { Çok sevdiğim bir besini yemeden önce, } \\
\text { ağzımın sulandığını hissediyorum }\end{array}$ \\
\hline
\end{tabular}

